Volume 2 Nomor 2 Desember 2017 hal 102-115

Avaliable online at: http://e-journal.unipma.ac.id/index.php/gulawentah

\title{
PENERAPAN PEMBELAJARAN KEWIRAUSAHAAN BERBASIS ETIKA BISNIS UNTUK MENINGKATKAN KEJUJURAN SISWA KELAS XI PERBANKAN SMK CENDEKIA MADIUN
}

\author{
Setyanti Nugraheni \\ SMK Cendekia Madiun \\ Email: setyanti1980@gmail.com
}

\begin{abstract}
Abstrak
Penelitian ini bertujuan untuk meningkatkan kejujuran siswa SMK melalui pembelajaran kewirausahaan berbasis etika bisnis. Melalui mata pelajaran kewirausahaan berbasis etika bisnis ini diharapkan mampu meningkatkan kejujuran dan membentuk karakter siswa yang mandiri, tangguh, percaya diri, pekerja keras yang mampu bersaing di era global. Penelitian ini menggunakan pendekatankualitatif kuantitatif (kombinasi) dengan jenis penelitian tindakan kelas (PTK). Subyek penelitiannya adalah siswa kelas XI Kompetensi Keahlian Perbankan SMK Cendekia Madiun.Penelitian tindakan kelas ini dilakukan kolaboratif dengan guru kelas XI Kompetensi Keahlian Perbankan SMK Cendekia Madiun sebagai pihak yang melakukan pembelajaran atau tindakan. Sedangkan pihak yang melakukan pengamatan terhadap proses tindakan adalah peneliti. Hasil penelitian menunjukkan bahwa melalui pembelajaran kewirausahaan berbasis etika bisnis dapat diketahui adanya peningkatan nilai kejujuran siswa. Nilai-nilai etika bisnis dimasukkan dalam langkah-langkah kegiatan pembelajaran di dalam Rencana Pelaksanaan Pembelajaran (RPP) yang disusun dan dikembangkan oleh guru kewirausahaan. Peningkatan ini dibuktikan dengan peningkatan rata-rata nilai kejujuran dari kondisi awal prasiklus ke tindakan siklus I dan siklus II, dan peningkatan jumlah siswa yang memperoleh predikat jujur.
\end{abstract}

Kata kunci: Kewirausahaan, Etika Bisnis, Kejujuran

\section{The Implementation of Learning Entrepreneurship Based on Business Ethics to Increase The Honest Study of Clas XI Banking SMK Cendekia Madiun}

\begin{abstract}
This study aims to improve the honesty of vocational students through entrepreneurial learning based on business ethics. Through entrepreneurial subjects based on business ethics is expected to improve honesty and form the character of students who are independent, tough, confident, hardworking that can compete in the global era. This research uses quantitative qualitative approach (combination) with type of action research class (PTK). The subjects of this research are the students of Grade XI of Banking Skills Competency of SMK Cendekia Madiun. This classroom action research is collaborative with teacher of class XI of SME Banking Skills Competence of Cendekia Madiun as the learning or action. While the observer of the action process is the researcher. The results showed that through entrepreneurial learning based on business ethics can be seen an increase in the value of student honesty. Business ethics values are incorporated in the learning activities steps in the Lesson Plans (RPPs) developed and developed by entrepreneurial teachers. This increase is evidenced by the increase in the average value of honesty from prasiklus initial conditions to the actions of cycle I and cycle II, and an increase in the number of students who get the honest predicate.
\end{abstract}

Keywords: Entrepreneurship, Business Ethics, Honesty 
gulawentah: Jurnal Studi Sosial

Volume 2 Nomor 2 Desember 2017 hal 102-115

Avaliable online at http://e-journal.unipma.ac.id/index.php/gulawentah

\section{Pendahuluan}

Pendidikan kewirausahaan merupakan suatu disiplin ilmu yang mempelajari nilai, kemampuan dan perilaku dalam menghadapi berbagai tantangan hidup. Kewirausahaan diajarkan sebagai suatu disiplin ilmu karena kewirausahaan memiliki badan pengetahuan yang utuh dan nyata, memiliki dua konsep yaitu memulai suatu usaha (venture start-up) dan perkembangan usaha (venture growth) serta memiliki objek tersendiri yaitu kemampuan menciptakan sesuatu. Dengan pembelajaran kewirausahaan diharapkan siswa dapat memiliki dan meningkatkan karakteristik seorang wirausaha, salah satunya yaitu karakter jujur. Sikap jujur dalam berwirausaha adalah mau dan mampu mengatakan sesuatu sesuai dengan keadaan yang sebenarnya. Jika diberi kepercayaan dalam berwirausaha tidak berkhianat, apabila berkata selalu benar dan apabila berjanji tidak mengingkari.

Namun, pembelajaran

kewirausahaan di SMK Cendekia ternyata belum memberikan hasil seperti yang diharapkan. Pembelajaran kewirausahaan belum mampu meningkatkan kejujuran siswa kelas XI Kompetensi Keahlian Perbankan SMK Cendekia Madiun. Tidak semua siswa mampu menerapkan semua pendidikan karakter yang telah diberikan, terutama karakter kejujuran. Perilaku tidak jujur banyak dilakukan, mulai dari siswa yang menyontek saat ulangan atau ujian, menjadi plagiat (mengambil/menyalin karya orang lain tanpa menyebutkan sumber), sering berkata dan berbuat tidak jujur dalam membuat laporan atau menyampaikan informasi, mencuri atau menyembunyikan uang atau barang berharga milik teman, dan tidak mengakui kesalahan atau kekurangan yang dimiliki.

Dari perilaku-perilaku tidak jujur yang dilakukan siswa kelas XI Kompetensi Keahlian Perbankan tadi, menimbulkan ketidakharmonisan dan kondisi yang tidak kondusif di dalam kegiatan pembelajaran di kelas, sehingga perlu dicari solusinya. Satu diantara solusinya adalah dengan menerapkan pembelajaran kewirausahaan berbasis etika bisnis. Pembelajaran kewirausahaan berbasis etika bisnis adalah pembelajaran kewirausahaan yang bertujuan untuk membentuk manusia secara utuh (holistik), sebagai insan yang memiliki karakter, pemahaman dan ketrampilan sebagai wirausahaberdasarkan nilai-nilai moral dan norma yang dijadikan tuntunan dalam berusaha dan memecahkan persoalan-persoalan yang dihadapi. Dengan etika bisnis ini diharapkan mampu meningkatkan kejujuran dan membentuk karakter siswa yang mandiri, tangguh, percaya diri, pekerja keras yang mampu bersaing di era global.

Berdasarkan latar belakang penelitian yang telah diuraikan di atas, maka masalah penelitian ini dapat dirumuskan yaituApakah penerapan pembelajaran kewirausahaan berbasis etika bisnis dapat meningkatkan kejujuran siswa Kelas XI Kompetensi Keahlian Perbankan SMK Cendekia Madiun.Sejalan dengan rumusan masalah di atas, maka secara garis besar penelitian ini bertujuan untuk untuk mengetahui peningkatan kejujuran siswa kelas XI Kompetensi Keahlian Perbankan SMK Cendekia Madiun melalui penerapan pembelajaran kewirausahaan berbasis etika bisnis.

Kewirausahaan merupakan sikap mental dan jiwa yang selalu aktif atau 
gulawentah: Jurnal Studi Sosial

Volume 2 Nomor 2 Desember 2017 hal 102-115

Avaliable online at http://e-journal.unipma.ac.id/index.php/gulawentah

kratif berdaya, bercipta, berkarsa dan bersahaja dalam berusaha untuk meningkatkan kualitas hidupnya.

Kewirausahaan adalah kemampuan untuk menciptakan sesuatu yang baru dan berbeda melalui cara berpikir kreatif dan bertindak inovatif untuk menciptakan peluang dalam menghadapi tantangan hidup. (Hudiyono, 2016: 3). Menurut Peter F. Drucker (dalam Kasmir, 2014: 20) mengatakan bahwa kewirausahaan merupakan kemampuan dalam menciptakan sesuatu yang baru dan berbeda. Pengertian ini mengandung maksud bahwa seorang wirausahawan adalah orang yang memiliki kemampuan untuk menciptakan sesuatu yang baru, berbeda dari yang lain, atau mampu menciptakan sesuatu yang berbeda dengan yang sudah ada sebelumnya. Sedangkan menurut Thomas W. Zimmerer, Norman (2014:4) mendefinisikan kewirausahaan adalah kemampuan menciptakan bisnis baru dengan mengambil risiko dan ketidakpastian demi mencapai keuntungan dan pertumbuhan dengan cara mengidentifikasi peluang dan menggabungkan sumber daya yang diperlukan untuk mendirikannya.

Robert D.Hisrich, Peters dan Sheperd yang dikutip Abraham dan Supri (2010:14) menyatakan bahwa: "Kewirausahaan adalah proses penciptaan sesuatu yang baru pada nilai menggunakan waktu dan upaya yang diperlukan, menanggung resiko keuangan, fisik, serta resiko sosial yang mengiringi, menerima imbalan moneter yang dihasilkan, serta kepuasan dan kebebasan pribadi”. Menurut Kau (dalam Sudrajad, 2012: 28) yang dimaksud kewirausahaan adalah suatu proses menciptakan sesuatu yang baru (kreasi baru) dan membuat sesuatu yang berbeda dari yang sudah ada (inovasi). Tujuannya adalah tercapainya kesejahteraan individu dan nilai tambah bagi masyarakat.

Etika berasal dari bahasa Yunani "Ethos" berarti adat istiadat atau kebiasaan, hal ini berarti etika berkaitan dengan nilai-nilai, tata cara hidup yang baik, aturan hidup yang baik, dan segala kebiasaan yang dianut dan diwariskan dari satu orang ke orang lain atau dari satu generasi ke generasi lainnya. Dalam bahasa Kant, etika berusaha menggugah kesadaran manusia untuk bertindak secara otonomdan bukan secara heteronom. Etika bermaksud membantu manusia untuk bertindak secara bebas, tetapi dapat dipertanggungjawabkan.

Menurut Agus Arijanto (dalam Mita, 2015:3) mengemukakan bahwa etika bisnis adalah suatu bagian yang tidak dapat dipisahkan dalam kegiatan bisnis yang dilakukan oleh para pelaku-pelaku bisnis. Masalah etika dan ketaatan pada hukum yang berlaku merupakan dasar yang kokoh yang harus dimiliki oleh pelaku bisnis dan akan menentukan tindakan apa dan perilaku bagaimana yang akan dilakukan dalam bisnisnya."

Pendapat yang senada dengan Agus Arijanto, Thomas W. Zimmerer dan Norman (2014:4) mendefinisikan etika bisnis adalah tatanan nilai moral dan standar-standar perilaku yang harus dihadapi oleh para pelaku bisnis sewaktu mereka membuat keputusan dan memecahkan masalah.

Sikap jujur adalah sebuah sikap yang selalu berupaya menyesuaikan atau mencocokan antara informasi dengan 
fenomena atau realitas. Sesuai kamus Indonesia kata "jujur" memiliki arti: tidak bohong; lurus hati; dapat dipercaya katakatanya; tidak khianat. Kejujuran mengacu pada segi karakter moral dan menunjukkanpositif, atribut berbudi seperti integritas, kejujuran, danketerusterangan bersama dengan adanya berbohong, menipu, ataupencurian (Poerwadarminta dalam Setiawan, 2013: 76). Menurut Sujarwa (2005) dalam Afrizal (2016:17) jujur atau kejujuran berati apa yang dikatakan seseorang akan sesuai dengan hati nuraninya. Jujur dapat pula diartikan sesorang yang bersih hatinya dari perbuatan-perbuatan yang dilarang oleh agama dan hukum. Menurut Hudiyono (2016: 10) kejujuran adalah nilai hidup yang bersifat universal. seorang manusia terletak pada kemampuannya untuk mewujudkan harapan dan cita-citanya, sebab keberhasilan mencapai sesuatu jika dilakukan secara konsisten maka menjadi kebiasaan. Prestasi dalam mencapai keberhasilan menjadi bermakna jika dilandasi kejujuran. Jujur dalam berwirausaha artinya mau dan mampu mengatakan sesuatu sebagaimana adanya.

Menurut Albert (2011:5) kejujuran adalah mengakui, berkata atau memberikan sebuah informasi yang sesuai kenyataan dan kebenaran, kejujuran tidaklah selalu tepat arti harfiahnya, dalam arti memiliki batasan-batasan dan lebih bersifat kondisional dalam aplikasinya sepanjang tidak keluar dari tujuan dan makna dasar. Menurut Galus (dalam Setiawan, 2013: 76) Perilaku tidak jujurdalam konteks pendidikan antara lain:

1. Plagiarisme (plagiarism), sebuah tindakan mengadopsi atau mereproduksi ide, atau kata-kata, dan pernyataanorang lain tanpa menyebutkan narasumbernya.

2. Plagiarisme karya sendiri (self plagiaris), menyerahkan/ mengumpulkan tugas yang sama lebih dari satu kali untukmata pelajaran yang berbeda.

3. Manipulasi (fabrication), pemalsuan data, informasi atau kutipan-kutipan dalam tugas-tugas akademis apapun.

4. Pengelabuan (deceiving), memberikan informasi yangkeliru, menipu terhadap guru berkaitan dengan tugastugasakademis.

5. Menyontek (cheating), berbagai macam cara untuk memperoleh atau menerima bantuan dalam latihan akademis tanpa sepengetahuan guru.

6. Sabotase (sabotage), tindakan untuk mencegah dan menghalang-halangi orang lain sehingga mereka tidak dapat menyelesaikan tugas akademis yang mesti mereka kerjakan.

Menurut Afrizal (2016: 18) Faktorfaktor yang menyebabkan manusia berbuat tidak jujur adalah karena adanya sifat iri hati/tidak rela, pengaruh lingkungan, social ekonomi, ingin popular, untuk sopan santun, dan untuk mendidik. Terjadinya kasus korupsi, penyalahgunaan kekuasaan, pemalsuan, plagiat, perselingkuhan, dan pembajakan hak cipta merupakan implementasi dari ketidakjujuran. Sedangkan menurut Hudiyono (2016:10) akibat dari ketidakjujuran dalam berwirausaha adalah sebagai berikut: (a) Tidak dipercaya masyarakat atau konsumen; (b) Menjadi rendah diri dan rasa malu; (c) Mudah tersinggung atau emosi; (d) Cepat iri dan dengki; (e) Suka dendam; (f) Prasangka buruk dan dusta; (g) Tidak punya teman; (h) Kehancuran dalam usahanya. 
gulawentah: Jurnal Studi Sosial

Volume 2 Nomor 2 Desember 2017 hal 102-115

Avaliable online at http://e-journal.unipma.ac.id/index.php/gulawentah

Kontribusi dari penerapan

pembelajaran kewirausahaan berbasis etika bisnis menurut peneliti adalah meningkatnya kejujuran sehingga siswa dipercaya teman dan guru, siswa menjadi rendah hati, tidak mudah tersinggung atau emosi, tidak iri dan dengki, tidak suka dendam, tidak mudah berprasangka buruk dan dusta, mempunyai banyak teman, kesusksesan dalam usahanya. Setelah siswa lulus sekolah dan menjadi seorang wirausaha, maka didunia usahanya tidak ada lagi praktik korupsi, tidak ada penyalahgunaan kekuasaan, tidak ada kasus pemalsuan, plagiat, perselingkuhan, pembajakan hak cipta.

\section{Metode Penelitian}

Penelitian ini menggunakan pendekatan kualitatif-kuantitatif atau kombinasi. Penelitian ini menggunakan pendekatan kualitatif kuantitatif (kombinasi) dengan jenis penelitian tindakan kelas (PTK). Subyek penelitiannya adalah siswa kelas XI Kompetensi Keahlian Perbankan SMK Cendekia Madiun dengan jumlah sebanyak 18 siswa yang terdiri dari 16 perempuan dan 2 laki-laki. Penelitian tindakan kelas ini dilakukan kolaboratif dengan guru kelas XI Kompetensi Keahlian Perbankan SMK Cendekia Madiun sebagai pihak yang melakukan pembelajaran atau tindakan. Sedangkan pihak yang melakukan pengamatan terhadap proses tindakan adalah peneliti. Adapun teknik pengumpulkan data yang digunakan dalam penelitian ini adalah observasi partisipatif. Artinya observer ikut serta dalam kegiatan atau situasi yang dilakukan oleh observant, diantaranya untuk mengetahui bagaimana perilaku jujur siswa pembelajaran dan instrumen yang digunakan yaitu anecdotal record (catatan anekdot).

Untuk memecahkan masalah penelitian yang telah disampaikan di depan, maka dilakukan langkah-langkah dalam penelitian tindakan kelas yang terdiri dari perencanaan, pelaksanaan tindakan, observasi, dan evaluasi-refleksi yang bersifat daur ulang atau siklus. Siklus akan terus dilakukan atau berlanjut apabila permasalahan belum terselesaikan.

Indikator kinerja penelitian disusun sebagai upaya untuk menentukan keberhasilan dari rencana penelitian yang telah disusun. Indikator kinerja membuat angka nyata sebagai ukuran atau pedoman menentukan peningkatan kejujuran siswa dalam mata pelajaran kewirausahaan, baik secara klasikal maupun individu. Secara individul, siswa dinyatakan jujur dalam kegiatan pembelajaran jika telah mencapai tingkat pengetahuan, sikap, dan keterampilan $80 \%$ yang ditunjukkan dengan perolehan nilai 80 atau lebih. Sedangkan secara klasikal mencapai minimal $80 \%$ dari siswa tuntas dalam belajar, maka pembelajaran yang dilakukan dikatakan dapat meningkatkan kejujuran siswa. Indikator tersebut secara rinci terdapat secara rinci terdapat pada tabel 1 
gulawentah: Jurnal Studi Sosial

Volume 2 Nomor 2 Desember 2017 hal 102-115

Avaliable online at http://e-journal.unipma.ac.id/index.php/gulawentah

Tabel 1 Indikator Kinerja Penelitian

\begin{tabular}{|c|c|c|}
\hline Rumusan Masalah & Tujuan & Indikator Kinerja \\
\hline $\begin{array}{l}\text { Apakah penerapan } \\
\text { pembelajaran } \\
\text { kewirausahaan berbasis } \\
\text { etika bisnis dapat } \\
\text { meningkatkan kejujuran } \\
\text { siswa Kelas XI } \\
\text { Kompetensi Keahlian } \\
\text { Perbankan SMK } \\
\text { Cendekia Madiun? }\end{array}$ & $\begin{array}{l}\text { Untuk mengetahui } \\
\text { peningkatan kejujuran } \\
\text { siswa kelas XI } \\
\text { Kompetensi Keahlian } \\
\text { Perbankan SMK } \\
\text { Cendekia Madiun } \\
\text { melalui penerapan } \\
\text { pembelajaran } \\
\text { kewirausahaan berbasis } \\
\text { etika bisnis. }\end{array}$ & $\begin{array}{l}\text { - Tidak menyontek dalam } \\
\text { mengerjakan ujian/ulangan, tidak } \\
\text { menjadi plagiat } \\
\text { mengambil/menyalin karya orang } \\
\text { lain tanpa menyebutkan sumber), } \\
\text { Mengungkapkan perasaan apa } \\
\text { adanya, menyerahkan kepada } \\
\text { yang berwenang barang yang } \\
\text { ditemukan, Membuatlaporan } \\
\text { berdasar-kan data atau informasi } \\
\text { apa adanya, mengakui kesalahan } \\
\text { atau kekurangan yang dimiliki } \\
\text { Kejujuran siswa meningkat } \\
\text { dengan penerapan pembelajaran } \\
\text { kewirausahaan berbasis etika } \\
\text { bisnis } \\
\text { 80\% siswa jujur }\end{array}$ \\
\hline
\end{tabular}

\section{Hasil dan Pembahasan}

Dari observasi yang telah dilakukan diperoleh gambaran awal bahwa guru Kewirausahaan dalam pembelajaran Kewirausahaan bersifat monoton, satu arah, kurang komunikatif, cenderung bersifat ceramah, siswa kurang terlibat aktif, guru belum menyampaikan muatan etika bisnis yang bisa memotivasi siswa untuk lebih jujur dalam bertutur kata maupun dalam bertingkah laku. Hasil capaian kejujuran dalam pembelajaran Kewirausahaan sebelum menggunakan pembelajaran berbasis etika bisnis sebagaimana tercantum pada tabel di bawah ini.

Tabel 2. Nilai Kejujuran pada Prasiklus

\begin{tabular}{lcc}
\hline \multicolumn{1}{c}{ Kriteria } & Jumlah Siswa & Presentase(\%) \\
\hline Sangat Baik (Selalu Jujur) & 0 & 0 \\
\hline Baik (Sering Jujur) & 9 & 50 \\
\hline Cukup (Kadang-kadang Jujur) & 9 & 50 \\
\hline Kurang (Tidak Pernah Jujur) & 0 & 0 \\
\hline Jumlah & 18 & 100 \\
\hline
\end{tabular}

Tabel 2 diatas menggambarkan bahwa nilai kejujuran siswa yang selalu jujur belum ada, siswa yang sering jujur sebanyak 9 orang atau $50 \%$ dan yang kadang-kadang jujur sebanyak 9 orang atau $50 \%$. Data ini menggambarkan bahwa tingkat kejujuran siswa kelas XI Kompetensi Keahlian Perbankan SMK Cendekia Madiun belum mencapai kriteria keberhasilan tindakan yang ditetapkanyaitu $80 \%$ siswa sering jujur dengan predikat B.

Dari hasil pengamatan pada prasiklus 
gulawentah: Jurnal Studi Sosial

Volume 2 Nomor 2 Desember 2017 hal 102-115

Avaliable online at http://e-journal.unipma.ac.id/index.php/gulawentah

menunjukkan bahwa tindakan yang

dilakukan oleh guru kewirausahaan sebagai kolaborator belum bisa meningkatkan kejujuran siswa. Oleh karena itu perlu adanya tindakan pada siklus I yaitu menerapkan pembelajaran kewirausahaan berbasis etika bisnis. a. Siklus I

$$
\text { Capaian hasil pelaksanaan }
$$

Siklus I penerapan pembelajaran Kewirausahaan berbasis etika bisnis dalam meningkatkan kejujuran siswa ditunjukkan pada tabel dibawah ini.

\section{Tabel 3 Nilai Kejujuran pada Siklus I}

\begin{tabular}{lcc}
\hline \multicolumn{1}{c}{ Kriteria } & Jumlah Siswa & Presentase $(\%)$ \\
\hline Sangat Baik (Selalu Jujur) & 0 & 0 \\
\hline Baik (Sering Jujur) & 13 & 72 \\
\hline Cukup (Kadang-kadang Jujur) & 5 & 27 \\
\hline Kurang (Tidak Pernah Jujur) & 0 & 0 \\
\hline Jumlah & 18 & 100 \\
\hline
\end{tabular}

Tabel 3 diatas menggambarkan bahwahasil penerapan pembelajaran Kewirausahaan berbasis etika bisnis pada siklus I yaitu siswa yang selalu jujur belum ada, siswa yang sering jujur sebanyak 13 orang atau $72 \%$ dan yang kadang-kadang jujur sebanyak 5 orang atau 27\%. Data ini menggambarkan bahwa tingkat kejujuran dalam pembelajaran kewirausahaan siswa kelas XI Kompetensi Keahlian Perbankan SMK Cendekia Madiun sudah mengalami peningkatan namun belum mencapai kriteria keberhasilan tindakan yang ditetapkanyaitu $80 \%$ siswa sering jujur dengan predikat $\mathrm{B}$.

Rata-rata nilai kejujuran siswa siklus I sebesar 2.6dari jmlah nilai sebesar 47 menunjukkan predikat baik (sering jujur) dan bila dibandingkan dengan nilai rata-rata prasiklus yaitu 2.4 mengalami kenaikan sebesar 0.2.Perbandingan dan kenaikan nilai rata-rata tersebut seperti gambar 1

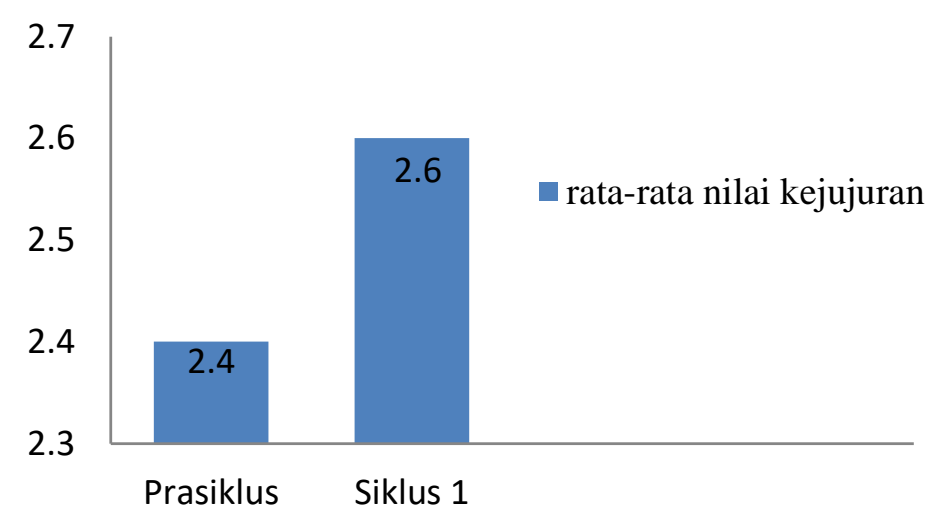

Gambar 1. Nilai rata-rta Prasiklus dan Siklus I

Jumlah siswa yang mencapai nilai kejujuran dengan predikat $\mathrm{B}$ (sering jujur) pada siklus 1 bila dibandingkan dengan prasiklus mengalami kenaikan dan nilai 
gulawentah: Jurnal Studi Sosial

Volume 2 Nomor 2 Desember 2017 hal 102-115

Avaliable online at http://e-journal.unipma.ac.id/index.php/gulawentah

kejujuran dengan predikat $\mathrm{C}$ (kadangkadang jujur) mengalami penurunan. Pada prasiklus, siswa yang mencapai predikat sering jujur sebanyak 9 orang $(50 \%)$ dan yang kadang-kadang jujur sebanyak 9 orang $(50 \%)$. Sedangkan pada siklus I, siswa yang mendapat nilai kejujuran dengan predikat B (sering jujur) mencapai sebanyak 13 orang $(72 \%)$ dan siswa yang mendapat nilai kejujuran dengan predikat $\mathrm{C}$ (kadang-kadang jujur) sebanyak 5 orang (27\%). Perbandingan nilai kejujuran tersebut dapat digambarkan seperti di bawah ini.

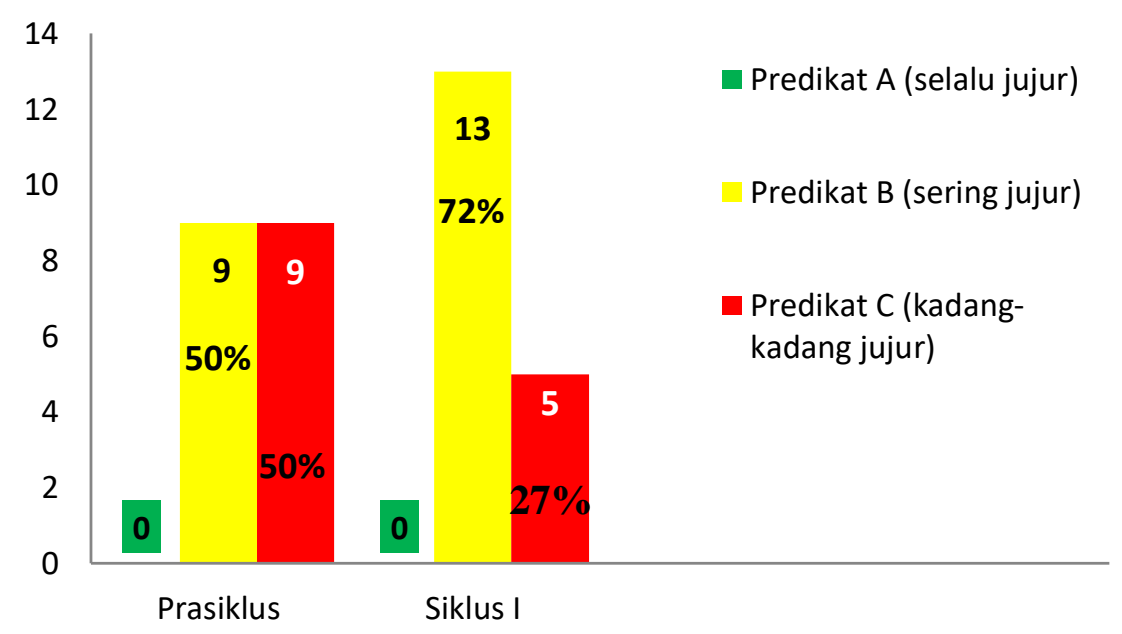

Gambar 2. Persentase Capaian Kejujuran Prasiklus dengan Siklus I

Tingkat kejujuran dengan predikat B (sering jujur) sebesar $72 \%$ tersebut di atas masih belum sesuai harapan atau di bawah indikator keberhasilan yang ditetapkan $\geq 80 \%$ dengan predikat $\mathrm{B}$ (sering jujur). Oleh karena itu perlu dilaksanakan siklus II dengan melakukan perbaikan yaitu guru dalam melaksanakan pembelajaran diupayakan lebih intensif dalam pembelajaran kewirausahaan dengan basis etika bisnis dengan menanamkan kebiasaan untuk bersikap jujur dalam segala hal.

b. Siklus II
Pelaksanaan tindakan penelitian pada siklus II dilaksanakan dalam 1kali pertemuan (2x45 menit).Dari observasi yang telah dilakukan diperoleh gambaran bahwa guru Kewirausahaan dalam pembelajaran Kewirausahaanberbasis etika bisnis bersifat komunikatif, siswa terlibat aktif, guru sudah menyampaikan muatan etika bisnis yang bisa memotivasi siswa untuk lebih jujur dalam bertutur kata maupun dalam bertingkah laku. Capaian hasil pelaksanaan Siklus II penerapan pembelajaran Kewirausahaan berbasis etika bisnis dalam meningkatkan kejujuran siswa ditunjukkan pada tabel dibawah ini.

Tabel 4 Nilai Kejujuran pada Siklus II

\begin{tabular}{lcc}
\hline \multicolumn{1}{c}{ Kriteria } & Jumlah Siswa & Presentase(\%) \\
\hline Sangat Baik (Selalu Jujur) & 2 & 11 \\
\hline Baik (Sering Jujur) & 16 & 88 \\
\hline
\end{tabular}


gulawentah: Jurnal Studi Sosial

Volume 2 Nomor 2 Desember 2017 hal 102-115

Avaliable online at http://e-journal.unipma.ac.id/index.php/gulawentah

\begin{tabular}{lcc}
\hline Cukup (Kadang-kadang Jujur) & 0 & 0 \\
\hline Kurang (Tidak Pernah Jujur) & 0 & 0 \\
\hline Jumlah & 18 & 100 \\
\hline
\end{tabular}

Tabel 4 diatas menggambarkan bahwa hasil penerapan pembelajaran Kewirausahaan berbasis etika bisnis pada siklus II yaitu siswa yang mencapai predikat selalu jujur sebanyak 2 orang (11\%) dan yang sering jujur sebanyak 16 orang $(88 \%)$ dan yang siswa yang kadangkadang jujur sebanyak 0 . Nilai tersebut di atas sudah sesuai harapan atau di atas indikator keberhasilan yang ditetapkan $\geq$ $80 \%$ dengan predikat B (sering jujur). Oleh karena itu tidak dilaksanakan siklus lanjutan.

Rata-rata nilai kejujuran siklus I sebesar 3.3menunjukkan predikat sangat baik (selalu jujur) dan bila dibandingkan dengan nilai rata-rata prasiklus yaitu 2.4 mengalami kenaikan sebesar 0.9 dan ratarata pada siklus I yaitu 2,6 mengalami kenaikan sebesar 0,6. Perbandingan dan kenaikan nilai rata-rata tersebut dapat digambarkan seperti di bawah ini

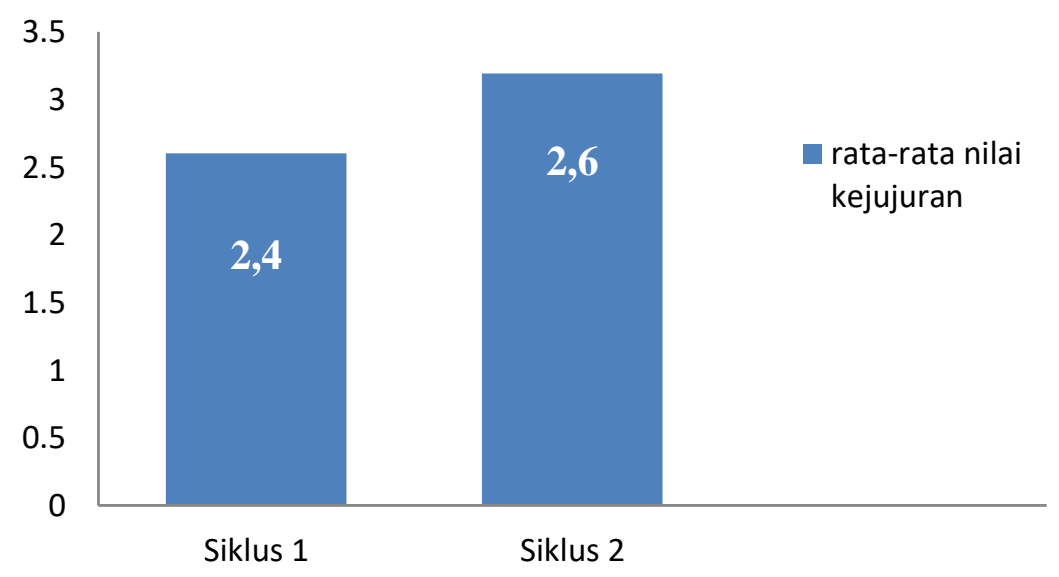

Gambar 3. Nilai Rata-rata Siklus I dan Siklus II

Jumlah siswa yang mencapai nilai kejujuran dengan predikat A (sangat jujur) pada siklus II bila dibandingkan dengan siklus 1 mengalami kenaikan dan yang sering jujur mengalami penurunan. Pada siklus II siswa yang mencapai predikat selalu jujur sebanyak 2 orang (11\%) dan yang sering jujur sebanyak 16 orang
(88\%). Sedangkan pada siklus I, siswa yang mendapat predikat B (sering jujur) mencapai sebanyak 15 orang (83\%) dan yang kadang-kadang jujur sebanyak 3 orang (16\%). Perbandingan nilai kejujuran tersebut dapat digambarkan seperti di bawah ini 
gulawentah: Jurnal Studi Sosial

Volume 2 Nomor 2 Desember 2017 hal 102-115

Avaliable online at http://e-journal.unipma.ac.id/index.php/gulawentah

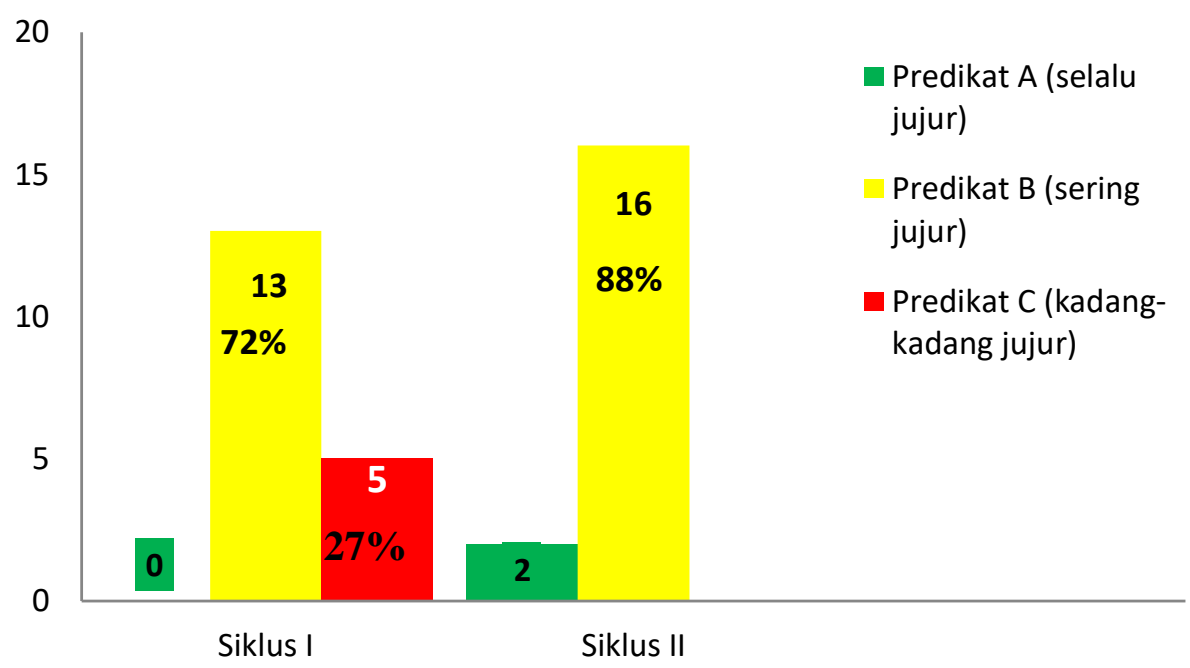

\section{Gambar 4. Persentase Capaian Nilai Kejujuran pada Siklus I dan Siklus II}

Tingkat kejujuran dengan nilai ratarata sebesar 3,19 menunjukkan bahwa nilai kejujuran siswa kelas XI mendapat predikat B (sering jujur) sebesar $88 \%$. Nilai tersebut di atas sudah sesuai harapan atau di atas indikator keberhasilan yang ditetapkan $\geq 80 \%$ dengan predikat $\mathrm{B}$ (sering jujur). Oleh karena itu tidak dilaksanakan siklus lanjutan.
Berdasarkan hasil observasi dan analisis data terdapat adanya peningkatan mengenai kejujuran siswa dalam pembelajaran Kewirausahaan dengan menggunakan basis etika bisnis pada siswa kelas XI Kompetensi Keahlian Perbankan SMK Cendekia Madiun dari siklus I ke siklus II.Gambar Hasil Peningkatan nilai kejujuran dapat dilihat pada tabel di bawah ini.

Tabel 5. Peningkatan Nilai Kejujuran

\begin{tabular}{lcccc}
\hline \multirow{2}{*}{ Kriteria } & \multicolumn{2}{c}{ Siklus I } & \multicolumn{2}{c}{ Siklus II } \\
\cline { 2 - 5 } & $\begin{array}{c}\text { Jumlah } \\
\text { Siswa }\end{array}$ & $\begin{array}{c}\text { Presentase } \\
(\%)\end{array}$ & $\begin{array}{c}\text { Jumlah } \\
\text { Siswa }\end{array}$ & $\begin{array}{c}\text { Presentase } \\
(\%)\end{array}$ \\
\hline Sangat Baik (Selalu Jujur) & 0 & 0 & 2 & 11 \\
\hline Baik (Sering Jujur) & 13 & 72 & 16 & 88 \\
\hline Cukup (Kadang-kadang Jujur) & 5 & 27 & 0 & 0 \\
\hline Kurang (Tidak Pernah Jujur) & 0 & 0 & 0 & 0 \\
\hline Jumlah & 18 & 100 & 18 & 100 \\
\hline
\end{tabular}

Tabel 5 menunjukkan bahwa pada siklus IIsiswa yang mendapat predikat A (selalu jujur) sebanyak 2 orang (11\%), siswa yang mendapat predikat B (sering jujur) sebanyak 16 orang ( $88 \%$ ) dan yang kadang-kadang jujur sebanyak 0
orang.Sedangkan pada siklus I, siswa yang mendapat predikat B (sering jujur) mencapai sebanyak 13 orang $(72 \%)$ dan yang kadang-kadang jujur sebanyak 5 orang $(27 \%)$.Data ini menggambarkan bahwa tingkat kejujuran dalam 
gulawentah: Jurnal Studi Sosial

Volume 2 Nomor 2 Desember 2017 hal 102-115

Avaliable online at http://e-journal.unipma.ac.id/index.php/gulawentah

pembelajaran kewirausahaan sudah mengalami peningkatan dan sudah mencapai kriteria keberhasilan tindakan yang ditetapkanyaitu $80 \%$ siswa sering jujur.

Rata-rata nilai kejujuran siklus I sebesar 3.3 menunjukkan predikat sangat baik (selalu jujur) dan bila dibandingkan dengan nilai rata-rata prasiklus yaitu 2.4 mengalami kenaikan sebesar 0.9 dan ratarata pada siklus I yaitu 2,6 mengalami kenaikan sebesar 0,6.Hal tersebut ditunjukkan dari nilai rata-rata klasikal seperti yang tergambar dalam gambar di bawah ini

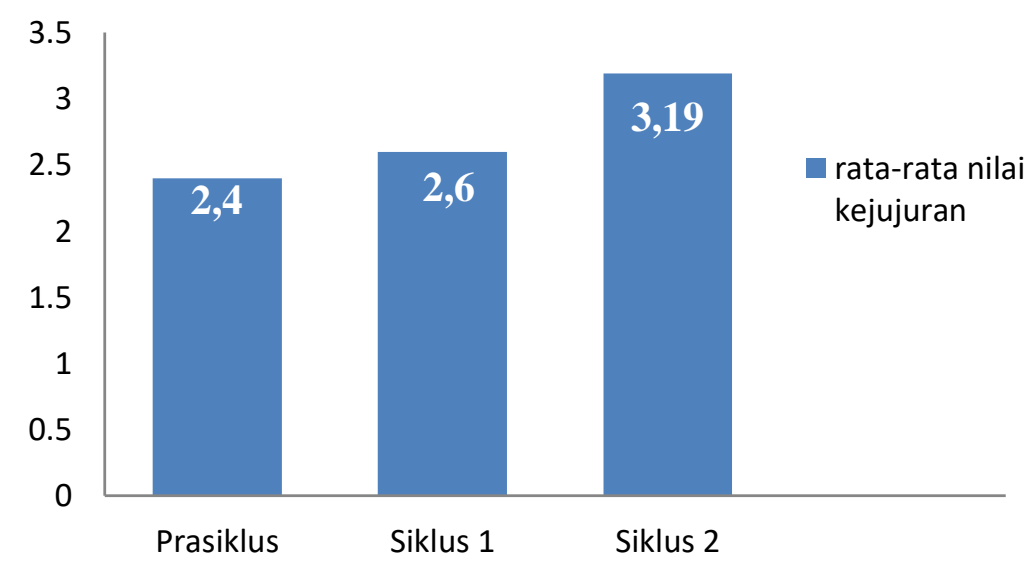

Gambar 5. Nilai Rata-rata Kejujuran Pada Prasiklus, Siklus I dan Siklus II

Tingkat kejujuran dengan nilai ratarata sebesar 3,19 menunjukkan bahwa nilai kejujuran siswa kelas XI mendapat predikat B (sering jujur) sebesar $88 \%$. Nilai tersebut di atas sudah sesuai harapan atau di atas indikator keberhasilan yang ditetapkan $\geq 80 \%$ dengan predikat $\mathrm{B}$ (sering jujur). Oleh karena itu tidak dilaksanakan siklus lanjutan.
Rekapitulasi rata-rata nilai kejujuran untuk masing-masing indikator kejujuran siswa kelas XI Kompetensi Keahlian Perbankan pada saat sebelum dilakukan penerapan pembelajaran kewirausahaan berbasis etika bisnis (prasiklus) dan setelah dilakukan tindakan pada siklus I dan siklus II dapat dilihat pada tabel dibawah ini.

Tabel 6. Rekapitulasi Rata-rata Nilai Kejujuran Untuk Tiap-tiap Indikator Kejujuran

\begin{tabular}{lcccc}
\hline \multicolumn{1}{c}{ Komponen Nilai } & Siklus 1 & Siklus 2 & Keterangan \\
\hline $\begin{array}{l}\text { Tidak menyontek dalam mengerjakan } \\
\text { ujian/ulangan }\end{array}$ & 2,6 & 3,3 & $\begin{array}{c}\text { Mengalami } \\
\text { peningkatan }\end{array}$ \\
\hline $\begin{array}{l}\text { Tidak menjadi plagiat (mengambil/menyalin karya } \\
\text { orang lain tanpamenyebutkan sumber) }\end{array}$ & 3,0 & 3,6 & $\begin{array}{c}\text { Mengalami } \\
\text { peningkatan }\end{array}$ \\
\hline $\begin{array}{l}\text { Mengungkapkan perasaan terhadap sesuatu apa } \\
\text { adanya }\end{array}$ & 2,4 & 3,0 & $\begin{array}{c}\text { Mengalami } \\
\text { peningkatan }\end{array}$ \\
\hline $\begin{array}{l}\text { Menyerahkan kepada yang berwenang barang } \\
\text { yang ditemukan }\end{array}$ & 2,7 & 3,1 & $\begin{array}{c}\text { Mengalami } \\
\text { peningkatan }\end{array}$ \\
\hline $\begin{array}{l}\text { Membuat laporan berdasarkan data atau informasi } \\
\text { apa adanya }\end{array}$ & 2,0 & 3,2 & $\begin{array}{c}\text { Mengalami } \\
\text { peningkatan }\end{array}$ \\
\hline
\end{tabular}


gulawentah: Jurnal Studi Sosial

Volume 2 Nomor 2 Desember 2017 hal 102-115

Avaliable online at http://e-journal.unipma.ac.id/index.php/gulawentah

\begin{tabular}{lcccccc}
\hline $\begin{array}{l}\text { Mengakui } \\
\text { dimiliki }\end{array}$ & kesalahan atau & kekurangan & yang & 3,0 & 3,1 & $\begin{array}{c}\text { Mengalami } \\
\text { peningkatan }\end{array}$ \\
\hline Jumlah & & & 15,7 & 19,2 & $\begin{array}{c}\text { Mengalami } \\
\text { peningkatan }\end{array}$ \\
\hline Rata-rata & & 2,6 & 3,19 & $\begin{array}{c}\text { Mengalami } \\
\text { peningkatan }\end{array}$ \\
\hline
\end{tabular}

Tabel 6 diatas dapat dilihat bahwa nilaikejujuran rata-rata untuk tiap tiap indikator kejujuran juga mengalami kenaikan.Sedangkan jumlah siswa yang mencapai nilai diatas dan atau sama dengan kriteria kejujuran sebelum pemberian tindakan sampai dengan pemberian tindakan (siklus 1 dan siklus II), yaitu jumlah siswa yang mendapat predikat A (selalu jujur) mengalami peningkatan, jumlah siswa yang mendapat predikat B (sering jujur) mengalami kenaikan, siswa yang mendapat predikat $\mathrm{C}$ (kadang-kadang jujur) mengalami penurunan. Hal tersebut dapat dilihat pada gambar dibawah ini.

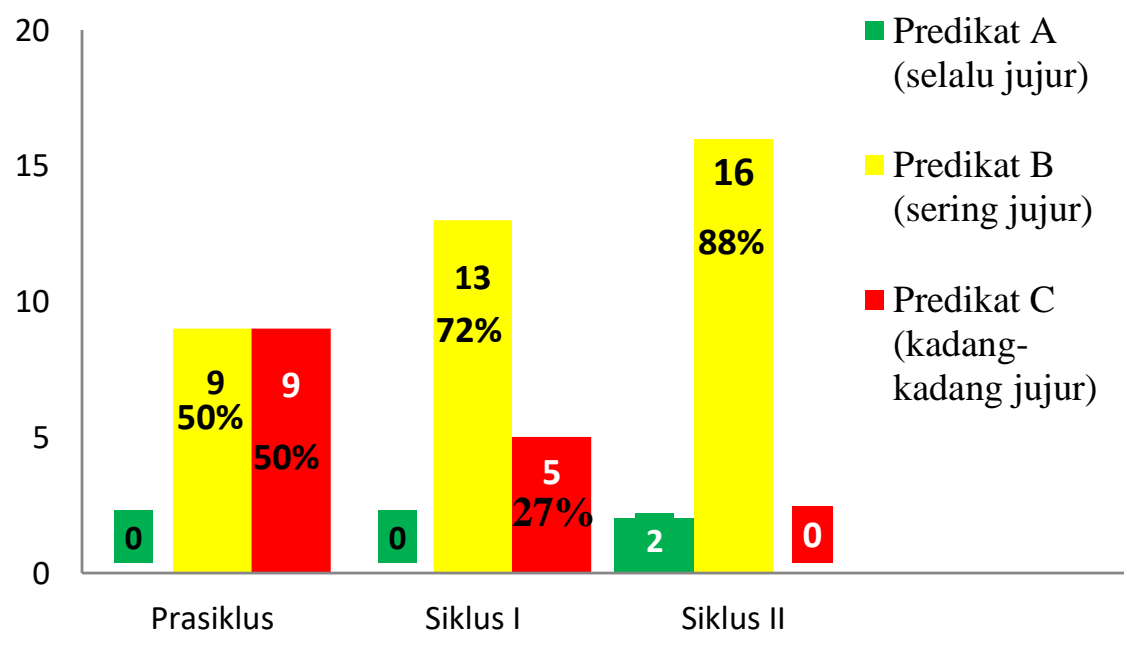

Gambar 6. Persentase Capaian Kejujuran pada Prasiklus, Siklus 1 dan Siklus II 
Avaliable online at http://e-journal.unipma.ac.id/index.php/gulawentah

Dengan demikian hipotesis tindakan yang menyatakan bahwa penerapan pembelajaran berbasis etika bisnis dapat meningkatkan kejujuran siswa kelas XI Kompetensi Keahlian Perbankan SMK Cendekia Madiun terbukti. Terbuktinya hipotesis tindakan penelitian ini memperkuat berbagai pendapat yang menyatakan bahwa dengan memasukkan nilai-nilai kejujuran ke dalam semua mata pelajaran secara umum dan khususnya pada mata pelajaran kewirausahaan dengan hasil diperolehnya kesadaran akan pentingnya nilai-nilai kejujuran tersebut, dan pembiasaan nilai-nilai jujur ke dalam tingkah laku siswa sehari-hari melalui proses pembelajaran, maka akan terbentuk karakter wirausaha yaitu jujur. Menurut Hudiyono (2016: 10) kejujuran adalah nilai hidup yang bersifat universal. Kemuliaan seorang manusia terletak pada kemampuannya untuk mewujudkan harapan dan citacitanya, sebab keberhasilan mencapai sesuatu jika dilakukan secara konsisten maka menjadi kebiasaan. Prestasi dalam mencapai keberhasilan menjadi bermakna jika dilandasi kejujuran.

Hasil penelitian yang dilakukan Rizali Hadi (2012) yang termuat dalam Jurnal Pendidikan Ekonomi dan Koperasi berjudu Pengembangan Model Internalisasi Nilai Kejujuran Melalui Pembelajaran Kewirausahaan Berbasis Etika Bisnis (Studi pada SMKNegeri 2 Banjarmasin) juga menunjukkan bahwa dengan model internalisasi nilai kejujuran menggunakan pembelajaran kewi-rausahaan, ada perubahan kejujuran yang signifikan pada siswa SMK Negeri 2 Banjarmasin.
Pendapat yang senada dengan hasil penelitian oleh Rizali Hadi tersebut diatas juga dikemukakan oleh Suherman (2012:12) bahwa untuk memahami karakteristik wirausahawan yaitu Energik-Modern - Antisipatif Naturalitatif-Smart-Urgent-HumanityEmpathy-Rasional-Motivation-

Attention-Need (Eman Suherman) tersebut diatas siswa dapat mempelajarinya melalui pembelajaran kewirausahaan, sehingga setelah melaksanakannya maka akan menumbuhkan karakteristik jujur.

\section{Kesimpulan}

Berdasarkan hasil penelitian dan pembahasan sebagaimana yang telah disampaikan pada bab sebelumnya, maka dapat disimpulkan bahwa sikap jujur dalam pembelajaran Kewirausahaan siswa kelas XI Kompetensi Keahlian Perbankan SMK Cendekia Madiun semester genap tahun pelajaran 2016/2017 dapat ditingkatkan dengan menggunakan pembelajaran kewirausahaan berbasis etika bisnis.

Peningkatan sikap jujur tersebut ditunjukkan dari nilai rata-rata klasikal yang mengalami kenaikan. Pada prasiklus nilai rata-rata klasikal $=2,4$, siklus $\mathrm{I}=2,6$, dan siklus II $=3,19$. Untuk penilaian kejujuran dari masingmasing indikator kejujuran juga mengalami kenaikan. Peningkatan nilai kejujuran juga dibuktikan dari jumlah siswa yang mendapat predikat A (selalu jujur). Pada prasiklus, siswa yang mendapat predikat C (kadang-kadang jujur) sebanyak 9 orang (50\%) dan yang mendapat predikat B (sering jujur) sebanyak 9 orang $(50 \%)$, tidak ada 
seorang pun yang mendapat predikat A (selalu jujur). Pada siklus I, siswa yang mendapat predikat $\mathrm{C}$ (kadang-kadang jujur) sebanyak 5 orang (27\%) dan yang mendapat predikat B (sering jujur) sebanyak 13 orang (72\%), tidak ada seorang pun yang mendapat predikat A (selalu jujur). Pada siklus II, tidak ada lagi siswa yang mendapat predikat $\mathrm{C}$ (kadang-kadang jujur), yang mendapat predikat B (sering jujur) sebanyak 16 orang (88\%), dan yang mendapat predikat A (selalu jujur) sebanyak 2 orang $(12 \%)$. Capaian nilai kejujuran tersebut sudah melebihi target yang ditetapkan atau sudah sesuai harapan atau di atas indikator keberhasilan yaitu $\geq 80 \%$ dengan predikat B (sering jujur).

Guru

mempertimbang-kan hendaknya pembelajaran berbasis etika bisnis sebagai salah satu metode pembelajaran, tidak hanya diterapkan untuk pembelajaran Kewirausahaan saja, tetapi dapat diterapkan pada pembelajaran mata pelajaran lain untuk meningkatkan kejujuran siswa, selalu menumbuhkan karakter atau sikap jujur dengan membiasakan hal-hal yang baik mulai dari hal yang kecil hingga hal yang besar. Pesan-pesan nilai kejujuran dalam berbisnis harus terus dilakukan secara terencana, agar kejujuran itu menjadi kebiasaan (habit).

\section{Daftar Pustaka}

Afrizal, J. (2016). Studi Tentang Kejujuran Dalam Suatu Sistem Organisasi. Yogyakarta: Harffey. Hudiyono. (2016). Revitalisasi SMK Melalui Kewirausahaan. Malang: Latif Kitto Mahesa.
Kasmir. (2014). Kewirausahaan Edisi Revisi. Jakarta: Raja Grafindo Perkasa.

Mita. (2015). Etika Bisnis. http://mitawulandari.blogspot.co.i d/2015/02/jurnal-etika-bisnis.html dipostkan Minggu, 08 Februari 2015. Diunduh 20 Desember 2016

Nurcahyo, A., Wahyudi, S., Setiawati, D. (2010). Kewirausahaan, Bahar Ajar Perguruan Tinggi. Magetan: Swastika Press.

Rizali Hadi. (2012). Pengembangan Model Internalisasi Nilai Kejujuran Melalui Pembelajaran Kewirausahaan Berbasis Etika Bisnis (Studi pada SMK Negeri 2 Banjarmasin). Vol 12 No. 1April 2012.http://jurnal.upi.edu/peneliti anpendidikan/view/3510/

Setiawan, F. (2013). Kemampuan Guru Melakukan Penilaian Dalam Pembelajaran Melalui Internalisasi Nilai Kejujuran Pada Pembelajaran Pendidikan Kewarganegaraan. Jurnal UPIIS Volume $5 \quad$ Nomor 2, Desember2013.

Suherman, E. (2012). Desain Pembelajaran Kewirausahaan. Bandung: Alfabeta

Zimmerer, T.W, Norman, S. (2014). Pengantar Kewirausahaan dan Manajemen Bisnis Kecil, Edisi Bahasa Indonesia. Jakarta: Indeks Gramedia. 